\title{
Alternative Diesel Grade Fuel Transformed from Polypropylene (PP) Municipal Waste Plastic Using Thermal Cracking with Fractional Column Distillation
}

\author{
Moinuddin Sarker*, Mohammmad Mamunor Rashid, Muhammad Sadikur Rahman, \\ Mohammed Molla \\ Department of Research and Development, Natural State Research Inc., Stamford, USA

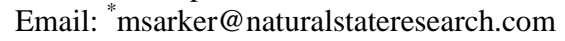

Received March 31, 2012; revised April 21, 2012; accepted May 5, 2012

\begin{abstract}
Day by day worldwide use of plastics is increasing because of their light weight and durable characteristics. Waste plastics are major environmental problems all over the world. Waste plastics are not bio-degradable, it remains in the landfill for a long period of time causing vegetation and aquatic ecosystem dilemmas. Abandoned waste plastic thrown into the ocean causes friction of ocean waves and then broken down by sunlight into small pieces and takes the shape of plastic like soup. Aquatic organism mistakes the plastic soup as their food and can't digest, either they die or through food chain it affects human health. To avoid severe environmental degradation problems of waste plastics some countries and big cities banned or restricted the use of plastic products. The worldwide generation of waste plastics is approximately 280 million tons/year. All most all of these waste plastics are dumped either in land or ocean. City municipalities spend huge amount of money each year just to dispose of these waste plastics into landfill because most waste plastics are not recycled. When the waste plastics are subjected to incineration, they release harmful toxic gas into the environment causing severe pollution. These waste plastics gradually enhance the hazardous environmental problems. Generally plastics are made from crude oil, however crude oil is a very limited natural resource and non-renewable. Every year millions of barrels of crude oil are to produce the waste plastics and when plastics are discarded after use the energy source is lost. A new developed technology plan minimizes the environment pollution problems simultaneously boost up energy sector by renovating the waste plastics into high energy content fuel. The produced fuel is obtained using a unique thermal degradation of waste plastics and converting them into hydrocarbon fuel like materials. Preliminary tests proved that this fuel burns cleaner and the production cost is very low. Unique production setup demonstrated to produce 93\% fuel from waste plastic in the pilot scale. The fuel produced has been tested and proven to work on majority types of internal combustion engines. This technology utilized can avoid waste plastic pollution problem worldwide by the implementation of newly developed technology. Through the utilization of the technology the use of reliable plastics won't need to be banned and serve as a very reliable alternate source of energy. The technology will also help reduce a significant amount of import oil from foreign countries and help provide a steady economy.
\end{abstract}

Keywords: Fuel; PP; Thermal Cracking; Fractional; Waste Plastic; Diesel; Polypropylene

\section{Introduction}

In recent years the production and consumption of plastics have increased drastically; as a consequence the responsible disposal of plastic wastes has created serious social and environmental arguments. At present both land filling and incineration of waste plastics are widely practiced. In, Japan, the percentage of waste plastic, as a fraction of municipal solid waste (MSW), that was land filled in the early 1980s was estimated to be $45 \%$, incineration was $50 \%$, and the other $5 \%$ was subjected to separation and recycling [1]. In the USA, more than $15 \%$ of the total

\footnotetext{
*Corresponding author.
}

MSW was incinerated in 1990; only about $1 \%$ of postconsumer plastic was recycled [2-4].

Municipal waste plastics normally remain a part of municipal solid wastes as they are discarded and collected as household wastes. Plastics usually account for about $7 \%$ of the total MSW by weight and much more by volume according to 1998 standard, this number is continuously increasing every year. In order to recycle municipal waste plastics separation of waste plastics from other household wastes is required. Although MSW separation technologies have studied extensively it is still not possible to completely classify MSW mechanically and obtain marketable fractions. House hold waste plastics are usually 
composed of coded plastics; HDPE, LDPE, PP, PS, PETE, PVC, and non coded plastics. Proper separations of these waste plastics are a big challenge and proper recycling and utilization of these waste plastics are even a bigger challenge.

Land filling of waste plastics is expected to decrease in the future as landfill space is depleted and waste plastics are resistant to environmental degradation. Co-incarnation of waste plastic wastes with other municipal solid wastes may be increasing practiced, because the high caloric value of plastics can enhance the heating value of MSW and facilitate an efficient incineration, while their energy content can also be recovered. But the potential relationship between plastics fed into an incineration and the formation of some highly toxic pollutants such as dioxins and furans is still unclear. It has been suggested that the chlorine content in PVC and other plastics is related to the formation of dioxins and furans, which are chlorinated polynuclear aromatic compounds. And although there is considerable evidence that these pollutants would still be generated in the absence of plastics, environment pressures against incineration have never completely disappeared. Thermal recycling of waste polymers under different catalytic and thermal circumstances has been well investigated by researchers [5-9]. Other important parameters for waste polymer degradation are residence time, and the chemical structure of polymer. The effects of these parameters have been less investigated and described. The packaging industry and other human activities use a huge amount of PE and PP. In a company collecting and handling communal and selective wastes, separation cannot be ideal thus the targeted polymer type always contains also other types of polymer. The processed materials are therefore polymer mixtures.

Thermal degradation of waste plastic, on the other hand, may provide an alternative means for disposal for disposal of plastic wastes with recovery of valuable gasoline-range hydrocarbons. In thermal cracking, waste plastics are heated to high temperatures, so their macromolecular structures are broken down into smaller molecules and a wide spectrum of hydrocarbons are formed. The products produced by this process can be divided into a gas fraction, a liquid fraction consisting of paraffin's, olefins, naphthelines and aromatics and solid residues. In catalytic cracking, more aromatics and naphthenes are selectively formed in the presence of commercial fluid cracking catalysts (FCC) or forming catalysts, so that the productively and economics of thermal cracking are improved. This paper reviews laboratory experiments on converting waste plastic samples to liquid hydrocarbon fuel utilizing the thermal degradation process.

\section{Materials and Method}

\subsection{Materials}

Disposable waste plastic collected from local grocery store and local restaurant. Waste plastic was mix with food particle and other materials. After collecting the raw materials they were washed with $7^{\text {th }}$ generation liquid soap into sink manually. Waste plastic was PP mix and PP waste plastic color was black and it was hard waste plastic. After washed waste plastic are cut into 4 - 5 inch pieces with scissor. 4 - 5 inch size waste plastic put into grinder mach for $2-3 \mathrm{~mm}$ size and this size fit into reactor for liquefaction process. During waste plastic washing period creating also waste water and this waste water was not discharge into drain system. Waste water kept into separate plastic container for treatment process. For waste water treatment purpose was use potash alum and sodium hydroxide and for sedimentation purposed used ventonite clay. Waste plastic to fuel production process fully cyclic process and save the environment problem.

\subsection{Pre-Analysis}

PP solid black color food container pre-analysis by using of TGA (pyris-1) for onset temperature measurement and temperature range was $50^{\circ} \mathrm{C}-800^{\circ} \mathrm{C}$. PP waste plastic sample run by TGA and TGA analysis result showed inflection point temperature $347.15^{\circ} \mathrm{C}$, onset temperature $299.26^{\circ} \mathrm{C}$ and sample was use for TGA analysis $3.43 \mathrm{gm}$, delta Y was $100.415 \%$. Sample was pre-analysis by TGA temperature versus weight. When temperature was increase gradually sample was decrease also gradually. From this TGA result we can calculate temperature profile for PP waste plastic to fuel production process. EA 2400 preanalysis result showed below Table $\mathbf{1}$ carbon, hydrogen and nitrogen percentage was significantly.

\subsection{Experimental Process}

Grounded Polypropylene (PP) waste plastic put into reactor chamber without catalyst. Reactor chamber put inside reactor and hook up condensation unit with reactor head. One by one setup collection tank, fuel purification device, light gas cleaning device. Reactor heated up electrically and reactor temperature range is $25^{\circ} \mathrm{C}-500^{\circ} \mathrm{C}$. Reactor has temperature controller and temperature controller name watlow. By using temperature controller temperature can monitor increase and decrease temperature profile into desire production process. PP waste plastic to fuel production process reactor setup was under labconco fume hood and full setup was fully air tight close system. During production period experiment was not vacuum system. PP waste plastic to fuel production

Table 1. EA-2400 PP plastic materials analysis results.

\begin{tabular}{lccccc}
\hline Plastic Name & Sample Weight (g) & C\% & H\% & N\% & S\% \\
\hline Polypropylene & 1.930 & 86.20 & 13.42 & 0.03 & 0.35 \\
\hline
\end{tabular}


temperature range was $100^{\circ} \mathrm{C}-380^{\circ} \mathrm{C}$ for liquefaction process. PP solid waste plastic was heated up from $100^{\circ} \mathrm{C}$ to up to $380^{\circ} \mathrm{C}$ gradually. Experimental start temperature was $100^{\circ} \mathrm{C}$ and temperature was increased $10^{\circ} \mathrm{C}$ every 15 minutes later. PP plastic melting point $160^{\circ} \mathrm{C}$ and our experiment was start from $100^{\circ} \mathrm{C}$. When temperature cross $160^{\circ} \mathrm{C}$ to $200^{\circ} \mathrm{C}$ noticed that vapor start to come out and some fuel drop arise. This experimental process inside reaction reacting endothermic reaction because heat applies is breaking down long chain bonding to short chain bonding. This PP waste plastic to fuel production experiment doesn't need any extra chemical or extra catalyst so far we analysis raw material by ICP and found that plastic has different kind of additives and metals. When waste plastic start to heating that time different kind of metal as a react like catalyst. At the end those metal increase a reaction performance. During PP waste plastic to fuel production did not use vacuum for that reason moisture was inside the reactor. When waste plastic start to melt, melt to liquid, liquid to vapor and vapor turn into liquid fuel by increase temperature profile. Experiment was performing until finished the whole process and final temperature was use $380^{\circ} \mathrm{C}$. From this experiment we collected liquid fuel, light gas and solid black residue. Light gas collected from collection tank and collection tank was connecting with light gas cleaning device. Gas cleaning device was half fill up with alkali solution and alkali solution normality was only $0.25(\mathrm{~N})$. Then light gas pass through from collection tank to alkali device and at the end light gas transfer into Teflon bag by using small motor pump for future use. Gas component was methane, ethane, propane, butane, carbon dioxide, hydrogen and carbon monoxide. By using gas cleaning device light gas was clean and transfer into Teflon bag for storage. PP waste plastic to fuel production technol- ogy liquid fuel yield percentage was 93\%, light gas was $4 \%$ and solid black residue was 3\%. Total electricity input for PP plastic to fuel 13 - $15 \mathrm{kWh}$. PP waste plastic to fuel density was $0.75 \mathrm{~g} / \mathrm{ml}$.

The method of converting waste materials into liquid fuel has it inefficiencies. It requires a large amount of electricity and energy to power the reactors. However, during the process a light gas in considerable amount is produced. That gas is similar to the natural gas used for cooking and heating. This process can reroute the gas produced during the production period and use it as a heat source instead of electricity. This method will considerably reduce the cost of conducting experiments.

$2^{\text {nd }}$ step process applied for diesel grade fuel production process. PP waste plastic to fuel was use for further fractional distillation process and making diesel grade fuel (see Figure 1). Fractional distillation column was use for fractional distillation process. Fractional distillation process set up 5 different columns with different temperature profile like low boiling point fuel to high boiling point fuel. Diesel grade fuel collected from $4^{\text {th }}$ fractional column and temperature range was $260^{\circ} \mathrm{C}$ to $285^{\circ} \mathrm{C}$. Fractional distillation process $4^{\text {th }}$ grade fuel was diesel fuel and diesel fuel density $0.80 \mathrm{~g} / \mathrm{ml}$. This fuel hydrocarbon compound also heavier and this fuel are not igniting. Collected diesel grade fuel percentage was 29\% and rest of all other fractional fuel percentage was 71\% including light gas also. Fractional distillation process was also generating some light gases. Light gas cleaning procedure also same above procedure. PP fuel to different fuel by using fractional distillation column used for heat applied with different column temperature wise and fuel break down into shorter into longer chain wise and come out into different fraction column then collected into different separate container for grade wise.

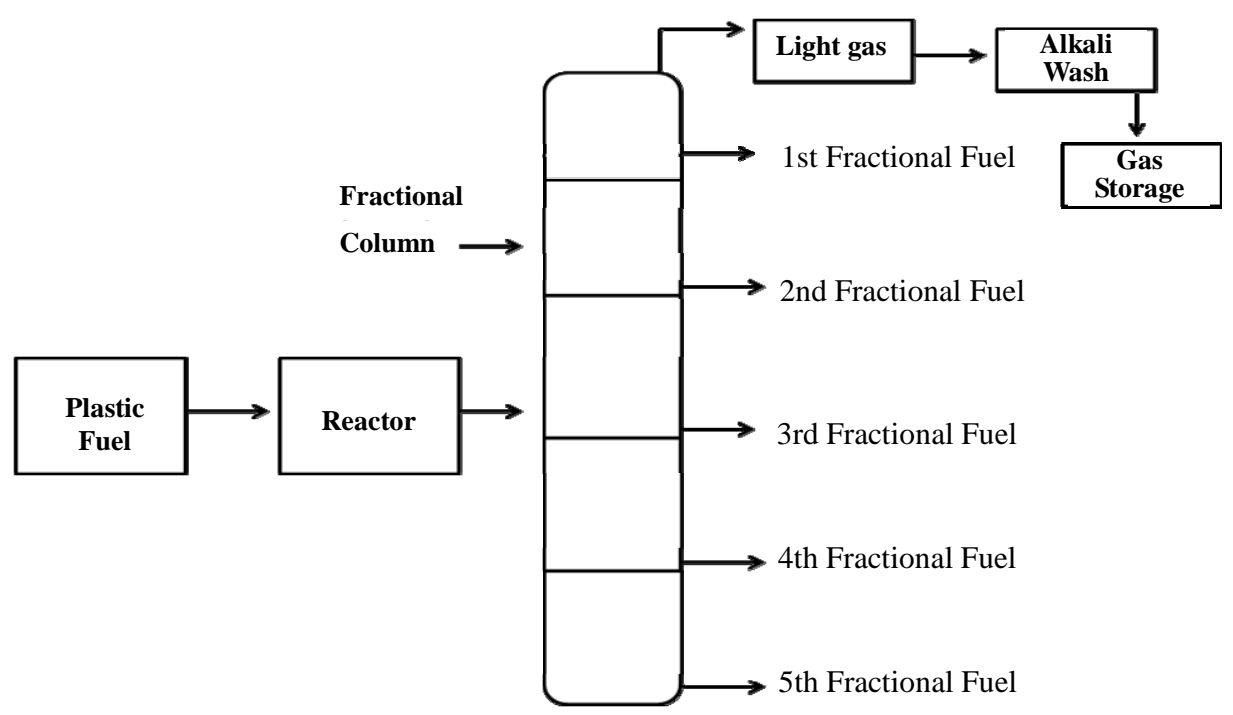

Figure 1. PP waste plastic fuel to $4^{\text {th }}$ fractional fuel production. 


\section{Results and Discussion}

The main point of this experiment is to extract the $4^{\text {th }}$ fractional fuel from the distillation column. The scope of it is to produce and analyze the diesel grade product that is generated. The result and discussion is solely based on the particular $4^{\text {th }}$ fractional fuel. Perkin Elmer FT-IR (Spectrum 100) used for raw sample per analysis and liquid sample analysis. Raw waste plastic sample analyzed by diamond crystal plate KRS-5 check there functional group and band energy value. Liquid fuel sample was analyzed by $\mathrm{NaCl}$ cell $0.025 \mathrm{~mm}$ thickness. Both samples analysis by same parameter used such as scan number was 32, resolution 4 and range $4000-450 \mathrm{~cm}^{-1}$. Perkin Elmer EA-2400 analyzer was used for raw waste plastics carbon; hydrogen and nitrogen percentages determine and follow ASTM method ASTM D5291.a. Carrier gas was used helium, oxygen and nitrogen. Perkin Elmer Thermogavimetric (TGA Pyris-1) was used for raw waste plastics onset temperature measuring. Temperature range used starting $50^{\circ} \mathrm{C}$ to $800^{\circ} \mathrm{C}$ and temperature ramping range used for onset temperature $10^{\circ} \mathrm{C} / \mathrm{min}$. Helium gas used as a carrier at 20 psi. Perkin Elmer Gas Chromatography and Mass Spectrometer (Clarus 500 series) used for raw waste plastic and liquid fuel analysis. Raw sample analysis purposed was used pyroprobe (CDS 5000) to volatile solid sample and transfer into GC column. Liquid sample analysis purposed was use auto sampler system. GC temperature profile for liquid sample analysis was initial temperature $40^{\circ} \mathrm{C}$ and hold for $1 \mathrm{~min}$ and final temperature $325^{\circ} \mathrm{C}$, hold for $15 \mathrm{~min}$. total experiment run time 44.50 minutes. GC column length 30 meter and mass program set up start mass 35 to 528 and ion mode EI+. Perkin Elmer Differential Scanning Calorimeter (DSC) was used for liquid fuel boiling point and fuel enthalpy value determination. Program temperature range was $0^{\circ} \mathrm{C}-400^{\circ} \mathrm{C}$ and temperature increased rate was $10^{\circ} \mathrm{C} / \mathrm{min}$. Carrier gas was use nitrogen at $20 \mathrm{ml} / \mathrm{min}$.

GC-MS Analysis of PP fuel to $4^{\text {th }}$ fractional fuel (Figure 2 and Table 2) in accordance with the various retention times and trace masses different types of hydrocarbon compounds are appeared in the analysis result index. Many compounds are emerged on the analysis carbon

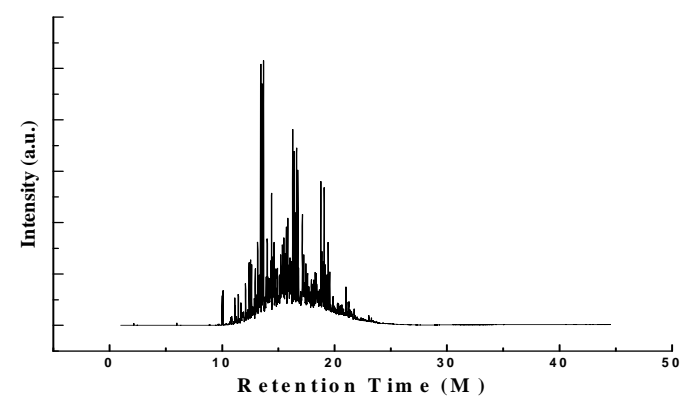

Figure 2. GC/MS Chromatogram of PP 4th fractional fuel.

Table 2. GC/MS Chromatogram of PP 4th fractional fuel compound list.

\begin{tabular}{|c|c|c|c|c|c|c|c|}
\hline $\begin{array}{c}\text { Peak } \\
\text { Number }\end{array}$ & $\begin{array}{l}\text { Retention } \\
\text { Time (M) }\end{array}$ & $\begin{array}{c}\text { Trace } \\
\text { Mass (m/z) }\end{array}$ & Compound Name & $\begin{array}{c}\text { Compound } \\
\text { Formula }\end{array}$ & $\begin{array}{c}\text { Molecular } \\
\text { Weight }\end{array}$ & $\begin{array}{c}\text { Probability } \\
\%\end{array}$ & $\begin{array}{c}\text { CAS } \\
\text { Number }\end{array}$ \\
\hline 1 & 10.00 & 41 & 2-Undecanethiol, 2-methyl- & $\mathrm{C}_{12} \mathrm{H}_{26} \mathrm{~S}$ & 202 & 4.54 & 10059-13-9 \\
\hline 2 & 10.08 & 41 & Cyclooctane, 1,4-dimethyl-, cis- & $\mathrm{C}_{10} \mathrm{H}_{20}$ & 140 & 3.61 & $13151-99-0$ \\
\hline 3 & 10.72 & 69 & 1-Isopropyl-1,4,5-trimethylcyclohexane & $\mathrm{C}_{12} \mathrm{H}_{24}$ & 168 & 28.2 & 219783-06-9 \\
\hline 5 & 10.86 & 41 & 4-Tridecene, (Z)- & $\mathrm{C}_{13} \mathrm{H}_{26}$ & 182 & 6.62 & $41446-54-2$ \\
\hline 6 & 11.14 & 55 & $\begin{array}{l}\text { Bicyclo[3.1.1]heptan-3-one, } \\
\text { 2,6,6-trimethyl-, }(1 \alpha, 2 \beta, 5 \alpha) \text { - }\end{array}$ & $\mathrm{C}_{10} \mathrm{H}_{16} \mathrm{O}$ & 152 & 5.28 & $15358-88-0$ \\
\hline 7 & 11.18 & 55 & 3-Tridecene & $\mathrm{C}_{13} \mathrm{H}_{24}$ & 180 & 3.96 & $60186-78-9$ \\
\hline 8 & 11.29 & 43 & 2,3-Dimethyldecane & $\mathrm{C}_{12} \mathrm{H}_{26}$ & 170 & 12.08 & $17312-44-6$ \\
\hline 9 & 11.44 & 69 & 1-Isopropyl-1,4,5-trimethylcyclohexane & $\mathrm{C}_{12} \mathrm{H}_{24}$ & 168 & 26.5 & 219783-06-9 \\
\hline 10 & 11.67 & 69 & 1-Isopropyl-1,4,5-trimethylcyclohexane & $\mathrm{C}_{12} \mathrm{H}_{24}$ & 168 & 12.8 & 219783-06-9 \\
\hline 11 & 11.91 & 41 & 2-Piperidinone, N-[4-bromo-n-butyl]- & $\mathrm{C}_{9} \mathrm{H}_{16} \mathrm{BrNO}$ & 233 & 24.4 & $195194-80-0$ \\
\hline 12 & 12.09 & 69 & 1-Isopropyl-1,4,5-trimethylcyclohexane & $\mathrm{C}_{12} \mathrm{H}_{24}$ & 168 & 19.3 & 219783-06-9 \\
\hline 13 & 12.27 & 41 & 5-Tetradecene, (Z)- & $\mathrm{C}_{14} \mathrm{H}_{28}$ & 196 & 6.91 & $41446-62-2$ \\
\hline 14 & 12.40 & 43 & Decane, 2,3,5,8-tetramethyl- & $\mathrm{C}_{14} \mathrm{H}_{30}$ & 198 & 8.54 & 192823-15-7 \\
\hline 15 & 12.53 & 43 & Decane, 2,3,5,8-tetramethyl- & $\mathrm{C}_{14} \mathrm{H}_{30}$ & 198 & 17.2 & $192823-15-7$ \\
\hline
\end{tabular}




\section{Continued}

\begin{tabular}{|c|c|c|c|c|c|c|c|}
\hline 16 & 12.56 & 41 & 2-Tridecene, (Z)- & $\mathrm{C}_{13} \mathrm{H}_{26}$ & 182 & 7.34 & 41446-59-7 \\
\hline 17 & 12.63 & 43 & Decane, 2,3,5,8-tetramethyl- & $\mathrm{C}_{14} \mathrm{H}_{30}$ & 198 & 17.4 & 192823-15-7 \\
\hline 18 & 12.74 & 55 & E-2-Octadecadecen-1-ol & $\mathrm{C}_{18} \mathrm{H}_{36} \mathrm{O}$ & 268 & 9.57 & N/A \\
\hline 19 & 12.87 & 41 & 2-Undecanethiol, 2-methyl- & $\mathrm{C}_{12} \mathrm{H}_{26} \mathrm{~S}$ & 202 & 4.87 & 10059-13-9 \\
\hline 20 & 13.17 & 43 & 7-Tetradecene & $\mathrm{C}_{14} \mathrm{H}_{28}$ & 196 & 3.41 & $10374-74-0$ \\
\hline 21 & 13.57 & 57 & 1-Heptadecene & $\mathrm{C}_{17} \mathrm{H}_{34}$ & 238 & 4.34 & $6765-39-5$ \\
\hline 22 & 13.69 & 84 & 1-Decanol, 2-methyl- & $\mathrm{C}_{11} \mathrm{H}_{24} \mathrm{O}$ & 172 & 4.82 & $18675-24-6$ \\
\hline 23 & 13.93 & 83 & (2,4,6-Trimethylcyclohexyl) methanol & $\mathrm{C}_{10} \mathrm{H}_{20} \mathrm{O}$ & 156 & 6.88 & $13702-56-2$ \\
\hline 24 & 14.01 & 69 & 1-Dodecanol, 3,7,11-trimethyl- & $\mathrm{C}_{15} \mathrm{H}_{32} \mathrm{O}$ & 228 & 3.14 & $6750-34-1$ \\
\hline 25 & 14.40 & 83 & (R)-(-)-(Z)-14-Methyl-8-hexadecen-1-ol & $\mathrm{C}_{17} \mathrm{H}_{34} \mathrm{O}$ & 254 & 4.79 & $30689-78-2$ \\
\hline 26 & 15.49 & 43 & Tetradecane, 2,6,10-trimethyl- & $\mathrm{C}_{17} \mathrm{H}_{36}$ & 240 & 10.1 & $14905-56-7$ \\
\hline 27 & 15.72 & 43 & Decane, 2,3,5,8-tetramethyl- & $\mathrm{C}_{14} \mathrm{H}_{30}$ & 198 & 10.5 & 192823-15-7 \\
\hline 28 & 15.84 & 43 & 1-Decanol, 2-hexyl- & $\mathrm{C}_{16} \mathrm{H}_{34} \mathrm{O}$ & 242 & 5.64 & $2425-77-6$ \\
\hline 29 & 16.74 & 55 & 1-Octadecene & $\mathrm{C}_{18} \mathrm{H}_{36}$ & 252 & 3.48 & $112-88-9$ \\
\hline 30 & 17.15 & 69 & (R)-(-)-(Z)-14-Methyl-8-hexadecen-1-ol & $\mathrm{C}_{17} \mathrm{H}_{34} \mathrm{O}$ & 254 & 4.80 & $30689-78-2$ \\
\hline 31 & 17.25 & 55 & 1-Eicosanol & $\mathrm{C}_{20} \mathrm{H}_{42} \mathrm{O}$ & 298 & 6.05 & $629-96-9$ \\
\hline 32 & 17.36 & 55 & Phytol & $\mathrm{C}_{20} \mathrm{H}_{40} \mathrm{O}$ & 296 & 8.45 & $150-86-7$ \\
\hline 33 & 17.59 & 69 & E-2-Octadecadecen-1-ol & $\mathrm{C}_{18} \mathrm{H}_{36} \mathrm{O}$ & 268 & 8.65 & N/A \\
\hline 34 & 17.95 & 43 & Tetradecane, 2,6,10-trimethyl- & $\mathrm{C}_{17} \mathrm{H}_{36}$ & 240 & 9.66 & $14905-56-7$ \\
\hline 35 & 18.88 & 69 & 9-Eicosene, (E)- & $\mathrm{C}_{20} \mathrm{H}_{40}$ & 280 & 3.23 & $74685-29-3$ \\
\hline 36 & 18.97 & 43 & 1-Docosene & $\mathrm{C}_{22} \mathrm{H}_{44}$ & 308 & 4.04 & $1599-67-3$ \\
\hline 37 & 19.09 & 69 & 1-Nonadecene & $\mathrm{C}_{19} \mathrm{H}_{38}$ & 266 & 4.38 & $18435-45-5$ \\
\hline 38 & 19.57 & 69 & $\begin{array}{c}\text { Dodecane, } \\
\text { 1-cyclopentyl-4-(3-cyclopentylpropyl)- }\end{array}$ & $\mathrm{C}_{25} \mathrm{H}_{48}$ & 348 & 5.38 & $7225-68-5$ \\
\hline 39 & 20.65 & 43 & Cyclopentane, (4-octyldodecyl)- & $\mathrm{C}_{25} \mathrm{H}_{50}$ & 350 & 4.05 & 5638-09-5 \\
\hline 40 & 21.09 & 43 & 1-Decanol, 2-hexyl- & $\mathrm{C}_{16} \mathrm{H}_{34} \mathrm{O}$ & 242 & 4.29 & $2425-77-6$ \\
\hline 41 & 21.27 & 43 & $\begin{array}{c}\text { Acetic acid, } \\
\text { 3,7,11,15-tetramethyl-hexadecyl ester }\end{array}$ & $\mathrm{C}_{22} \mathrm{H}_{44} \mathrm{O}_{2}$ & 340 & 3.57 & N/A \\
\hline 42 & 23.05 & 43 & 1-Nonadecanol & $\mathrm{C}_{19} \mathrm{H}_{40} \mathrm{O}$ & 284 & 3.06 & $1454-84-8$ \\
\hline 43 & 23.27 & 69 & 1-Heptacosanol & $\mathrm{C}_{27} \mathrm{H}_{56} \mathrm{O}$ & 396 & 4.28 & 2004-39-9 \\
\hline
\end{tabular}

range $\mathrm{C}_{12}$ to $\mathrm{C}_{27}$ at temperature $260^{\circ} \mathrm{C}$ carbon chains of hydrocarbon breaking down into different ranges among them few of compounds are discussed. Based on the retention time and trace mass following hydrocarbon compounds as follows such as at the initial phase of the analysis at retention time 10.0 and trace mass 41, compound is 2-Undecanethiol, 2-methyl-(C12H26S), retention time 10.08 and trace mass 41 , compound is Cyclooctane, 1,4-dimethyl-, cis-( $\mathrm{C} 10 \mathrm{H} 20)$, retention time 10.86 and trace mass 41, compound is 4-Tridecene, $(\mathrm{Z})-\left(\mathrm{C}_{13} \mathrm{H}_{26}\right)$, retention time 11.91 and trace mass 41 ,compound is 2Piperidinone, N-[4-bromo-n-butyl]-, (C9H16BrNO), retention time 12.27 and trace mass 41 , compound is 5Tetradecene, $(\mathrm{Z})-\left(\mathrm{C}_{14} \mathrm{H}_{28}\right)$, retention time 12.87 and trace mass 41, compound is 2-Undecanethiol, 2-methyl- $\left(\mathrm{C}_{12} \mathrm{H}_{26} \mathrm{~S}\right)$, retention time 13.17 and trace mass 43 ,compound is 7Tetradecene $\left(\mathrm{C}_{14} \mathrm{H}_{28}\right)$, retention time 13.93 and trace mass 83 , compound name is (2,4,6-Trimethylcyclohexyl) 
methanol $\left(\mathrm{C}_{10} \mathrm{H}_{20} \mathrm{O}\right)$, retention time 14.01 and trace mass 69,compound name is 1-Dodecanol, 3,7,11-trimethyl$\left(\mathrm{C}_{15} \mathrm{H}_{32} \mathrm{O}\right)$, retention time 14.40 and trace mass 83 , compound is (R)-(-)-(Z)-14-Methyl-8-hexadecen-1-ol $\left(\mathrm{C}_{17} \mathrm{H}_{34} \mathrm{O}\right)$, retention time 15.84 and trace mass 43 , compound is 1 Decanol, 2-hexyl- $\left(\mathrm{C}_{16} \mathrm{H}_{34} \mathrm{O}\right)$, retention time 16.74 and trace mass 55 , compound is 1-Octadecene $\left(\mathrm{C}_{18} \mathrm{H}_{36}\right)$, retention time 17.36 and trace mass 55, Phytol $\left(\mathrm{C}_{20} \mathrm{H}_{40} \mathrm{O}\right)$, retention time 17.95 and trace mass 43 , compound is E-2-Octadecadecen-1-ol $\left(\mathrm{C}_{18} \mathrm{H}_{36} \mathrm{O}\right)$, retention time 18.88 and trace mass 69, compound is 9-Eicosene, $(\mathrm{E})-\left(\mathrm{C}_{20} \mathrm{H}_{40}\right)$, retention time 19.09 and trace mass 69 , compound is 1-Nonadecene $\left(\mathrm{C}_{19} \mathrm{H}_{38}\right)$, retention time 19.57 and trace mass 69, compound is Dodecane, 1-cyclopentyl-4-(3-cyclopeantylpropyl)- $\left(\mathrm{C}_{25} \mathrm{H}_{48}\right)$. Ultimately also at retention time 23.05 and trace mass 43 , compound is 1-Nonadecanol $\left(\mathrm{C}_{19} \mathrm{H}_{40} \mathrm{O}\right)$ and ultimately retention time 23.57 and trace mass 69 , compound is 1-Heptacosanol $\left(\mathrm{C}_{27} \mathrm{H}_{56} \mathrm{O}\right)$ respectively FTIR

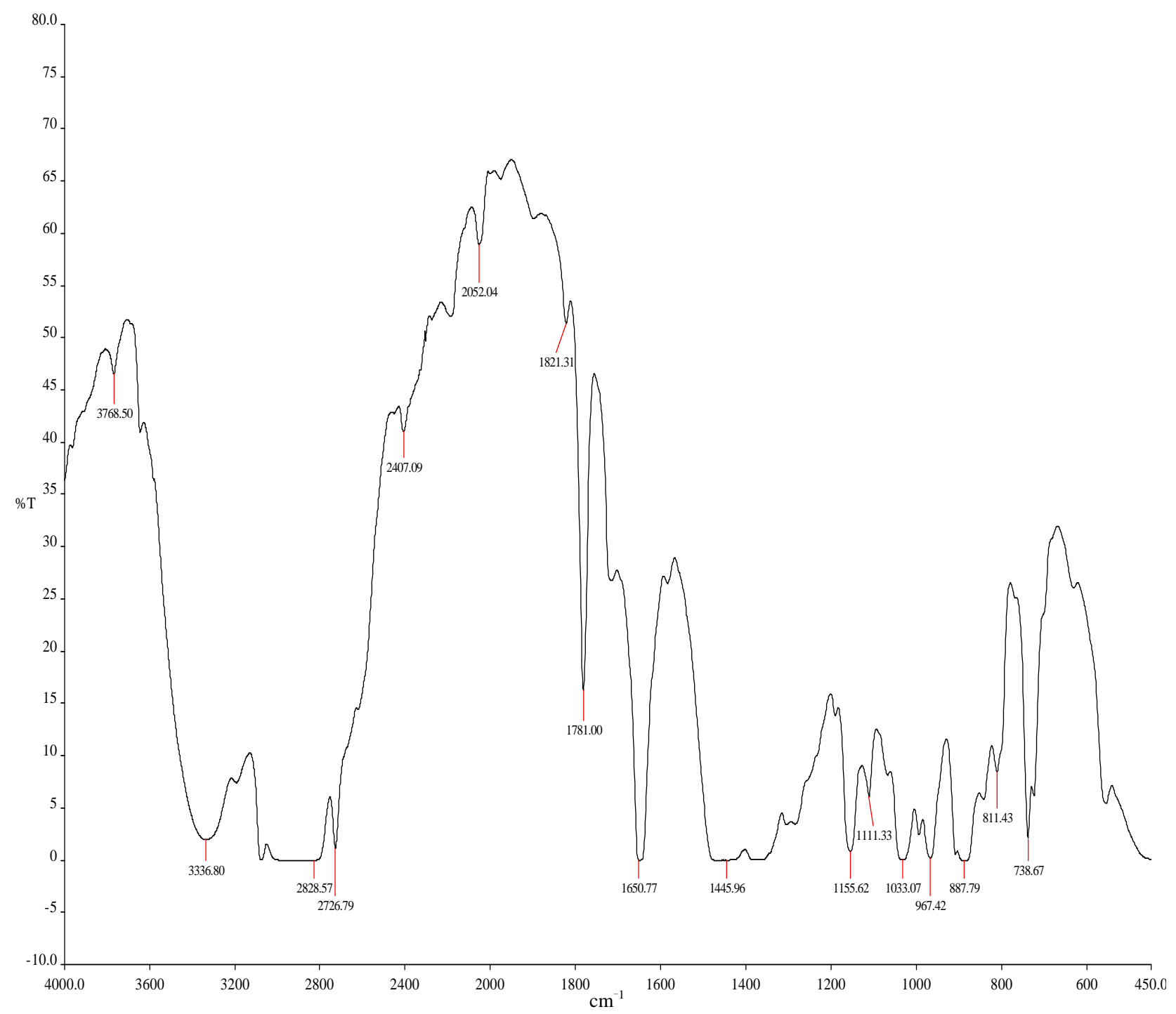

Figure 3. FT-IR Spectrum of PP 4th fractional fuel. analysis of PP fuel to $4^{\text {th }}$ fractional fuel (Figure 3 and Table 3) according to their wave number and spectrum band following types of functional groups are appeared in the analysis. In the spectrum field we noticed that higher wave number are emerged in the initial phase and middle index of the spectrum and in higher wave number small and bulky both functional groups are available and in low wave number double bond and single bond functional groups are available such as methane group, cis and trans alkene etc. Hereafter wave number wave number $3336.80 \mathrm{~cm}^{-1}$ functional group is Intermolecular $\mathrm{H}$ bonds, wave number $2828.57 \mathrm{~cm}^{-1}$ and 2726.79 functional group is $\mathrm{C}-\mathrm{CH}_{3}$, wave number $1821.31 \mathrm{~cm}^{-1}$ and $1781.00 \mathrm{~cm}^{-1}$ functional group is Non-Conjugated, wave number $1445.96 \mathrm{~cm}^{-1}$ functional group is $\mathrm{CH}_{3}$, wave number $887.79 \mathrm{~cm}^{-1}$ functional group is $\mathrm{C}=\mathrm{CH}_{2}$, and ultimately wave number $738.67 \mathrm{~cm}^{-1}$ functional group is - $\mathrm{CH}=\mathrm{CH}-$ (cis) respectively. 
Table 3. PP 4th fractional fuel functional group name.

\begin{tabular}{ccc}
\hline Number of Wave Wave Number in $\mathbf{~ c m}^{\mathbf{- 1}}$ & Functional Group Name \\
\hline 1 & 3336.80 & Intermolecular H bonds \\
2 & 2828.57 & $\mathrm{C}-\mathrm{CH}_{3}$ \\
3 & 2726.79 & $\mathrm{C}-\mathrm{CH}_{3}$ \\
4 & 1821.31 & Non-Conjugated \\
5 & 1781.00 & Non-Conjugated \\
6 & 993.43 & $-\mathrm{CH}=\mathrm{CH}_{2}$ \\
7 & 1650.77 & $-\mathrm{CH}=\mathrm{CH}-($ trans $)$ \\
8 & 1445.96 & $\mathrm{CH}$ \\
9 & 887.79 & $\mathrm{C}=\mathrm{CH}$ \\
10 & 738.67 & $-\mathrm{CH}=\mathrm{CH}-($ cis $)$ \\
\hline
\end{tabular}

PP waste plastic fuel to $4^{\text {th }}$ fractional fuel analysis by DSC equipment for fuel (seen Figure 4) boiling point and enthalpy value measured. $50 \mu \mathrm{L}$ fuels were used for boiling analysis by DSC. This fraction fuel grade is similar to diesel fuel because when fuel fraction temperature was use $260^{\circ} \mathrm{C}-285^{\circ} \mathrm{C}$. This fuel is not ignitable because this fuel has heavy compound structure. From DSC graph showed fuel boil start at temperature $5.26^{\circ} \mathrm{C}$ mega watt was $0.0482 \mathrm{~mW}$. Graph onset temperature was shown $7.36^{\circ} \mathrm{C}$. Fuel peak temperature showed 184.16 and peak height was $51.1034 \mathrm{~mW}$. Peak end showed from this graph $226.54 \mathrm{~mW}$. Fuel enthalpy value showed from this graph delta $\mathrm{H}$ is $21260.4749 \mathrm{~J} / \mathrm{g}$ and area $21260.475 \mathrm{~mJ}$. At $50^{\circ} \mathrm{C}$ fuel boil percentage was $12.40 \%$ only. At $250^{\circ} \mathrm{C}$ fuel boil percentage was $98.06 \%$, finally $100 \%$ finished was $393.52^{\circ} \mathrm{C}$ temperature and mega watt was 0.0364 $\mathrm{mW}$. This fuel compound was heavy and fuel category is look like diesel fuel category.

ASTM test was performed by $3^{\text {rd }}$ party laboratory Intertek, New Jersey, USA. ASTM all test performed ASTM test method wise. Sulfur (ASTM D5453), water and sediment (D2709), kinematic viscosity @100 F (D445), cetane number (D613), cloud point (D5773), cold filter plugging point (D309), copper corrosion (D 130), gross heat of combustion (D240), API gravity @ 60 F (D4052), dry vapor pressure (D5191), electric conductivity (D 2624) etc.

\section{Conclusion}

The $4^{\text {th }}$ fraction of the PP-5 fuel is considered to be in a diesel grade category. The fuel contains a lot of heavy compounds since it is collected only at the second procedure of the fractional distillation. The fuels' density is $0.80 \mathrm{~g} / \mathrm{ml}$ and since it has these heavy compounds it is unable to ignite in room temperature. Also this fuel has a peak boiling point of $184.16^{\circ} \mathrm{C}$. The fuels' boiling point is high because it has a lot of materials that ended up in the fuel since it was collected $260^{\circ} \mathrm{C}-280^{\circ} \mathrm{C}$. The high

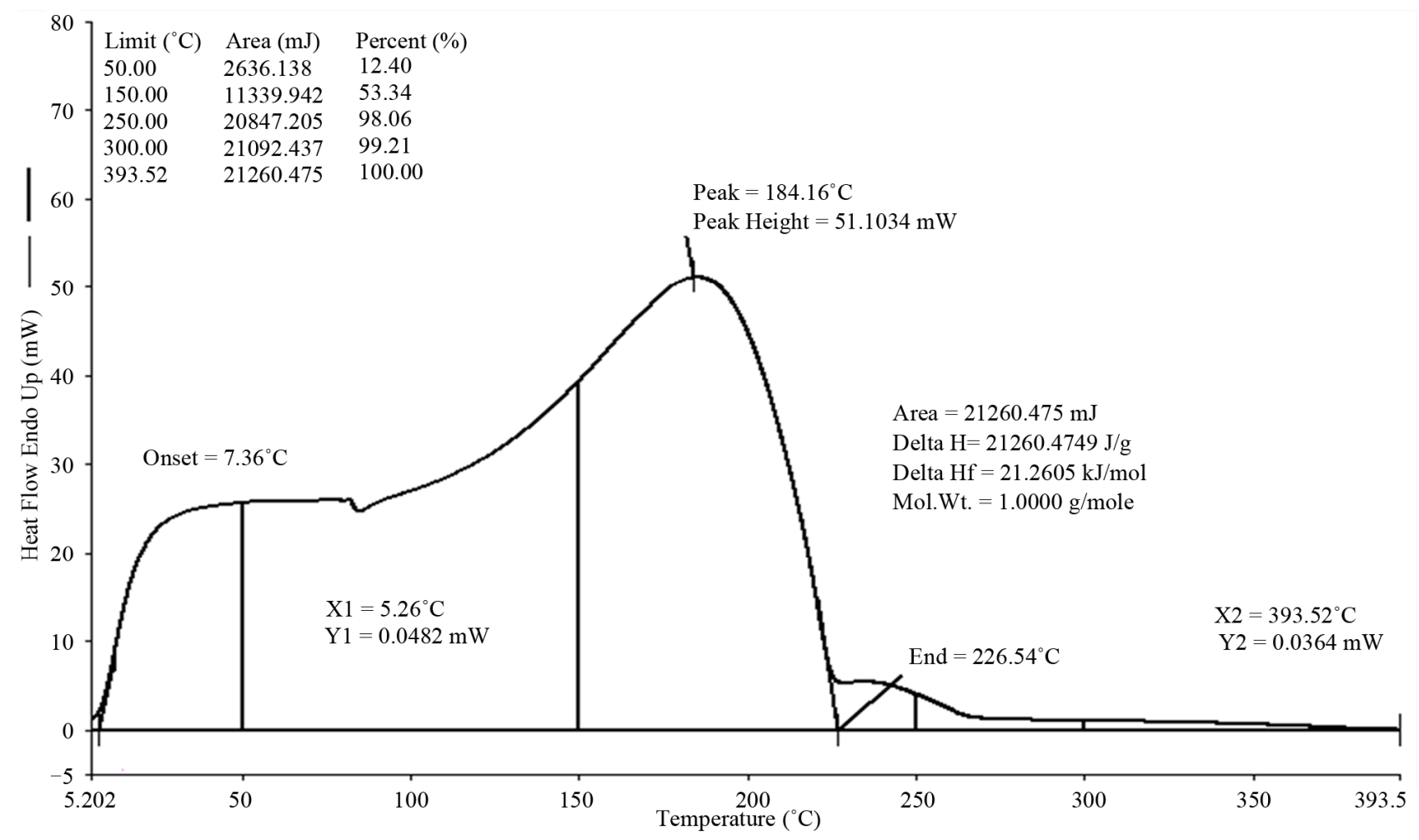

Figure 4. DSC graph of PP $4^{\text {th }}$ fractional fuel. 
end fuel is collected at 340 so we can see that the $4^{\text {th }}$ fraction will most definitely contain byproducts of the plastics inside it.

\section{Acknowledgements}

The author acknowledges the support of Dr. Karin Kaufman, the founder and sole owner of Natural State Research, Inc (NSR). The authors also acknowledge the valuable contributions NSR laboratory team members during the preparation of this manuscript.

\section{REFERENCES}

[1] Plastic Wastes, "Recovery and Recycling in Japan,” Plastic Waste Management Institute, Tokyo, 1985

[2] G. D. Andrew and P. M. Subramanian, "Emerging Technologies in Plastics Recycling,” ACS Publications, Washington DC, 1992.

[3] T. R. Curlee and S. Das. "Identifying and Assessing of Opportunity for Plastics Recycling," Resources, Conservation and Recycling, Vol. 5, No. 4, 1991, pp. 343-363. doi:10.1016/0921-3449(91)90012-D

[4] H. Yakowitz. "Incineration of Municipal Solid Waste: Scientific and Technical Evaluation of the State-of-theArt by an Expert Panel," Resources, Conservation and Recycling, Vol. 4, No. 3, 1990, pp. 241-251.
doi:10.1016/0921-3449(90)90005-O

[5] H. Kim and J. W. Lee, "Effect of Ultrasonic Wave on the Degradation of Polypropylene Melt and Morphology of Its Blend with Polystyrene,” Polymer, Vol. 43, No. 8, 2002, pp. 2585-2589. doi:10.1016/S0032-3861(02)00017-4

[6] J. Yanga, R. Mirand and C. Roy, "Using the DTG Curve Fitting Method to Determine the Apparent Kinetic Parameters of Thermal Decomposition of Polymers," Polymer Degradation and Stability, Vol. 73, No. 3, 2001, pp. 455-461. doi:10.1016/S0141-3910(01)00129-X

[7] Y. H. Lin and P. N. Sharratt, "Conversion of Waste Plastics to Hydrocarbons by Zeolited Catalytic Pyrolysis," Journal of the Chinese Institute of Environmental Engineering, Vol. 10, 2000, pp. 271-277.

[8] A. D. Chirico, M. Armanini, P. Chini, P. Cioccolo, F. Provasoli and G. Audisio, "Flame Retardants for Polypropylene Based on Lignin,” Polymer Degradation and Stability, Vol. 79, No. 1, 2002, pp. 139-145. doi:10.1016/S0141-3910(02)00266-5

[9] K. Jayaraman, "Manufacturing Sisal-Polypropylene Composites with Minimum Fibre Degradation," Composites Science and Technology, Vol. 63, No. 3-4, 2003, pp. 367374. doi:10.1016/S0266-3538(02)00217-8 